\title{
Development of interactive multimedia based on lectora inspire in kingdom
} monera material

\section{Sayyidah Asmah ${ }^{(D *}$, Laili Fitri Yeni, Titin}

Faculty of Teacher Training and Education, Universitas Tanjungpura, Jl. J.A. Yani, Pontianak (78I24), West Kalimantan, Indonesia

"Corresponding author: sayyidahasmah@gmail.com

\section{Article Info}

Article History:

Received 30 November 2019

Revised 23 December 2019

Accepted I7 July 2020

Published 30 November 2020

\section{Keywords:}

Kingdom monera

Lectora inspire

Interactive multimedia

Response

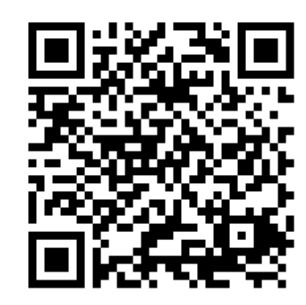

ABSTRACT

Interactive multimedia based on Lectora inspire referred to in this research was learning media of based ICT created to use the Lectora inspire computer program. This research aims to develop learning media and determine students' responses to interactive multimedia based on Lectora inspire that appropriate to be used as learning media in the kingdom monera. This research was the ADDIE development model consisting of five stages of analyzing, design, develop, implement, and evaluate. The students response questionnaire consisted of 3 aspects namely cognitive, affective, and conative consisting was 22 items. Research subjects is students of class XI in SMA Negeri 2 Pontianak, SMA Negeri I0 Pontianak, and MAN I Pontianak. The results of interactive multimedia based on Lectora inspire validation for the eligibility to obtain a Content Validity Index value was $\mathrm{I} .00$ and declared valid. A small-scale trial consisting of 18 students received an average rating is a good category. Whereas a large-scale trial consisting of 36 students obtained an average score in the very good category. The results obtained it was concluded that interactive multimedia based on Lectora inspire was suitable for use as a medium in schools and there needs to be implemented to see acheviement.

(C) 2020 Asmah et al

This is an open access article under the CC-BY-SA license

Citation: Asmah, S., Yeni, L.F., \& Titin. (2020). Development of interactive multimedia based on lectora inspire in kingdom monera material. JPBIO (Jurnal Pendidikan Biologi), 5(2), I I4-I26. DOI: https://doi.org/I0.3I932/jpbio.v5i2.562

\section{INTRODUCTION}

The curriculum of 2013 is a curriculum that applies in a form of an effort to prepare the quality of learning by the needs of 2Ist-century competencies to answer the needs and challenges of an increasingly sophisticated and modern era. Therefore, the implementation of learning in the curriculum of 2013 is expected to be able to implement the availability of sophisticated dol I0.31932/jpbio.v5i2.562 Asmah et al jurnaljpbio@gmail.com 
technological and information tools in the learning process. This is by the regulation of Permendikbud No. 70 (2013) which states that the use of the curriculum of 2013 is used to refine the mindset into interactive learning and the motives for learning a single tool or to create multimedia learning.

Biology has specific material that is different from other sciences, namely the study of living things, the environment, and the relationship between the two. The role of science, especially biology, is very strategic for learning, especially in preparing future students who are critical, creative, competitive, able to solve problems and dare to make decisions quickly and correctly so that they can survive productively during the swift waves of competition in the global digital era full of opportunities and challenges (Sudarisman, 20I5). Learning biology is something done by students, actively, and doing something instead of finding conclusions or concepts about nature. Therefore, the need for tools or learning media to facilitate teachers and students in the learning process.

Based on the results of the direct interview with biology teachers in April in three schools in Pontianak, it was found that the completeness of student learning outcomes in the kingdom monera material remained incomplete under the minimum completeness criteria determined by the school, namely was 75. The Research of Cimer (2012) students' difficulties in studying biology due to the large number concepts or topics in biology that are exact that require understanding and application as well as biology are the sciences that seek to express material relating to living things and the environment, so students sometimes have difficulty in mastering the subject.

Students also have difficulty in understanding the concept of kingdom monera material because the object being studied is abstract (microscopic). It is difficult to understand, the many scientific or Latin names that are hard to remember by students and the use of lecture methods with the help of PowerPoint media and student worksheets. Research Purnomo (2017) kingdom monera material including material that is difficult to understand by students. Difficulties in understanding kingdom monera material because the object being studied is microscopic and its existence is difficult to observe without using tools such as the media so need learning media that can help convey messages properly (Cimer, 20I2).

The school was not possible to do practicum because of the limited tools and materials such as Petri dishes which were very limited in number. This is in line with Kholina, Pribadi, \& Ridlo, (20I3) in class X SMK N I Kalibagor learning biology in the kingdom monera material mostly uses the method that was always used in every other material, namely lecture method besides the practical implementation in the laboratory was rarely done because it was constrained by tools and materials.

Learning must be designed as closely as possible so that students do not feel forced or depressed and students are expected to be more active both physically as well as mentally and can attract attention and interest in learning so students can focus their attention (Heni, Hilarius, \& Markus, 2017). According to Daryanto (2016), many types of ICT are utilized as one of the learning media, namely there are computer-based ones that are offline or online. One of learning media based ICT is interactive multimedia of based Lectora inspire. Lectora inspire is a computer program from the very beginning of its manufacture functions as a compiler for multimedia components to support the e-learning process (Mas'ud, 20I4). They develop interactive media that needs to be supported by several media components including text, graphics, images, video, animation, audio, and interactivity (Suratman, 2019).

The importance of Lectora inspire media to help this learning process because basically, the learning process is a communication process. The communication process must be created and realized through learning activities and exchanging messages between the teacher and students. The message or information can be in the form of knowledge, skills, abilities, ideas, experiences, and so 
forth which is poured and displayed or delivered to students with Lectora inspire (Zuhri \& Rizaleni, 2016). The excellence of Lectora inspire by using Lectora inspire, the subject matter is designed as attractive as possible, can display videos, and animated images related to the subject matter so that students pay more attention to what is conveyed by the teacher (Shalikhah, Primadewi, \& Iman, 2017). The learning process will be more fun and meaningful so that the effect on increasing student learning achievement.

The use of learning technology can change the learning process in the old classrooms in general students only hear, see, mimic what is said by the teacher and the text in the book, but with technology, students can receive information not only from the teacher and textbook but also other interactive media so students can construct knowledge and understanding socially (Zuhrieh, 2009). Interactive multimedia based on Lectora inspire in this research will be applied via an android smartphone. Android is one of the mobile operating systems that grow amid other operating systems that are currently developing (Matsun, Ramadhani, \& Lestari, 2018) The advantages of learning using mobile learning can be used independently both in school and outside school (Muyaroah \& Fajartia, 2017). Mobile learning creates learning that is not bound by location and time so that it is more flexible, interactive, communicative, and dynamic (Zakia, Refirman, \& Rusdi, 2009).

The use of interactive multimedia based on Lectora inspire is expected to be able to make students interested in learning in kingdom monera material so that it can improve student learning outcomes and motivate students and interactive multimedia is appropriate to be used as a learning medium. This is supported by research conducted by Rahmawati \& Isroah (2013) the use of interactive multimedia based on Lectora inspire can improve learning outcomes and motivate students to pay attention to the presentation of material presented. Based on the description above, researchers are interested in developing interactive multimedia based on Lectora inspire, so that it can be seen the feasibility of interactive multimedia based on Lectora inspire in kingdom monera material and student responses to interactive multimedia based on Lectora inspire in kingdom monera class X material in senior high school.

\section{RESEARCH METHODS}

Research Design

The research design used in this research was research $\&$ development methods (R\&D). It is research methods used to produce certain products and test the effectiveness of the product. The model used in the research refers to Tegeh, Jampel, \& Pudjawan (20I4) namely the analysis, design, development, implementation, evaluate model (ADDIE). ADDIE model is a simple and easy procedural model for producing a medium for short-term research (Hasyim, 2016).

\section{Instrument}

The instrument used was a media validation sheet and a student questionnaire response sheet. The media validation sheet covers four aspects namely; a) format (Clarity of work instructions, suitability of interactive multimedia formats based on Lectora inspire, harmony of colors, writing, and images in interactive multimedia based on Lectora inspire, appropriateness of video size and video sound contained in Lectora inspire as well as text displayed in interactive multimedia based on Lectora inspire and the suitability of the layout of the writing used in lectora inspire based interactive multimedia, b) content (Conformity of material content is adjusted to basic competence, achievement index and learning objectives, clarity of the concept of kingdom monera delivered on interactive multimedia based on Lectora inspire, suitability of LKPD in Lectora inspire with basic competencies, indicators and learning objectives, suitability of evaluation questions contained in Lectora inspire with kingdom monera material in the material suitability of 
images in interactive multimedia based on lectora inspire based in kingdom monera material, ease in understanding the material presented in interactive multimedia based on Lectora inspire), c) language (ease in understanding the language used, effectiveness of sentences used, use of language according to perfect spelling) and; d) illustration (ease of navigation (interactive multimedia based navigation buttons Lectora inspire) (Priyono \& Asto, 20I2).

The student response questionnaire used a Likert scale with four rating scales (criteria), namely Strongly Agree (SA), Agree (A), Disagree (D), and Strongly Disagree (SD) (Riduwan, 2015; Bustami, Corebima, Suarsini, \& Ibrohim, 2017). The response questionnaire was validated by three validators consisting of 2 lecturers in the FKIP Untan biology education study program and one teacher on biology subjects. The response questionnaire was made with two statements, namely a positive statement and a negative statement, and consisted of three dimensions, namely; a) cognitive (Understanding contents of interactive multimedia based on Lectora inspire, Clarity of learning instructions, Appropriate Lectora inspire appearance); b) affective (motivation, attractiveness, and curiosity); and c) conative (tendency to use Lectora inspire). The validation assessment of interactive multimedia based on Lectora inspire was I.00 and valid categories. The validation results from the student response questionnaire are feasible to use.

\section{Procedures}

The research procedure consisted of five stages, namely: a) Analyze, the stages carried out in the analysis stage were as follows: (I) competency analysis was carried out an analysis of basic competencies obtained basic competence 3.5 Identifying the structure, way of life, bacterial reproduction and the role of bacteria in life. (2) characteristic analysis was carried out characteristic analysis conducted observations and interviews in three schools and (3) material analysis was carried out analysis of material contained in the 2013 X class Senior High School syllabus X 3.5 Identifying the structure, way of life, bacterial reproduction and the role of bacteria in life; $b$ ) Design, the stages carried out in the design as follows: (I) formulating objectives in accordance with specified basic competencies; (2) determining the order of presentation of material, illustrations, and interactive multimedia based on Lectora inspire visualizations; (3) writing the initial draft of interactive multimedia product based on Lectora inspire and making storyboards; $\mathrm{c}$ ) Development, the stages carried out in the development are as follows: (I) the stage of making lectora inspire which includes, making template or background Lectora inspire, installing images, installing videos, making a student worksheet, and making evaluation questions; (2) the stage of converting multimedia lectora inspire to the form of CD-Room publications for laptops or netbooks and zip format HTML publications, so that it can be built into the shape of an Android application with the help of Appsgeyser digoogle The finishing stage (finishing), namely reviewing and testing interactive multimedia based readability lectora inspire; (3) Carry out formative evaluation, which is conducting media validation and product revisions that have been suggested at the time of validation by the validator; (4) carrying out the preparation of research instruments in the form of student response questionnaires which are then validated by the validator; $d$ ) Implement, the stages carried out in the implementation are as follows: (I) conducting a small-scale trial of I8 class XI students; (2) conducting large-scale trials on 36 students of class XI; e) Evaluate, the stages carried out in the evaluation are as follows: (I) conduct a formative evaluation that is the product revision that has been suggested by the validator; (2) conducting an evaluative that is knowing the students' responses to interactive multimedia based on Lectora inspire.

\section{Data Analysis}

The results of Lectora-based interactive multimedia validation were analyzed using Lawshe for the formula Content Validity Ratio (CVR) to see the average per-indicator, Content Validity 
Index (CVI) to see the average aspect as a whole while the students' responses using a percentage formula by calculating the percentage of the total score acquisition per item.

\section{RESULTS}

The purpose of this research was to determine the feasibility and response of students to interactive multimedia based on Lectora inspire in the kingdom monera material class X Senior High School. Interactive multimedia based on Lectora inspire kingdom monera material validated by 5 validators. The results of interactive multimedia validation based on Lectora inspire using Lawshe calculations can be seen in Table I. Based on Table I it was found that all the criteria for interactive multimedia based on Lectora inspire were declared valid because of a CVR value was I.00. The minimum limit for a data declared valid was 0.99 for a validator of 5 people (Lawshe, 1975). The results also showed the CVI value obtained was I.00. This shows that interactive multimedia based on Lectora inspire is appropriate to be used as a learning media in kingdom monera class X.

The student responses that have been measured in this study consist of 22 statements and are composed of 3 aspects namely cognitive aspects which are composed of three indicators, namely the understanding of interactive multimedia contents based on Lectora inspire, clarity of learning instructions and the suitability of interactive multimedia displays based on Lectora inspire.

Table I. Results of interactive multimedia validation based on lectora inspire by 5 validators

\begin{tabular}{|c|c|c|c|c|c|c|c|c|}
\hline \multirow{2}{*}{ Aspect } & \multirow{2}{*}{ Indicator } & \multicolumn{5}{|c|}{ Validator } & \multirow[t]{2}{*}{ CVR } & \multirow[t]{2}{*}{$\mathrm{C}$} \\
\hline & & I & 2 & 3 & 4 & 5 & & \\
\hline \multirow{5}{*}{ Format } & Clarity of work instructions. & 3 & 4 & 4 & 4 & 4 & 1.00 & Valid \\
\hline & $\begin{array}{l}\text { The formats suitability of interactive } \\
\text { multimedia based on Lectora inspire }\end{array}$ & 3 & 4 & 4 & 4 & 4 & 1.00 & Valid \\
\hline & $\begin{array}{l}\text { Color harmony, writing, and images in } \\
\text { interactive multimedia based on Lectora } \\
\text { inspire. }\end{array}$ & 3 & 4 & 4 & 3 & 3 & 1.00 & Valid \\
\hline & $\begin{array}{l}\text { The suitability of the video size and video } \\
\text { sound contained in the Lectora inspire as well } \\
\text { as the writings that are displayed in } \\
\text { Interactive Multimedia based on the Lectora } \\
\text { inspire }\end{array}$ & 3 & 4 & 3 & 3 & 3 & 1.00 & Valid \\
\hline & $\begin{array}{l}\text { The suitability of the layout of the writing } \\
\text { used in interactive multimedia based on } \\
\text { Lectora inspire. }\end{array}$ & 3 & 3 & 3 & 4 & 3 & $\mathrm{I} .00$ & Valid \\
\hline \multirow{4}{*}{ Content } & $\begin{array}{l}\text { The suitability of the contents of the material } \\
\text { is adjusted to the basic competencies, } \\
\text { indicators, and learning objectives }\end{array}$ & 4 & 4 & 4 & 4 & 3 & $\mathrm{I} .00$ & Valid \\
\hline & $\begin{array}{l}\text { The clarity of the concept of kingdom } \\
\text { monera is delivered on interactive multimedia } \\
\text { based on Lectora inspire }\end{array}$ & 3 & 3 & 4 & 4 & 3 & $\mathrm{I} .00$ & Valid \\
\hline & $\begin{array}{l}\text { The suitability of LKPD in Lectora inspire } \\
\text { with basic competencies, indicators, and } \\
\text { learning objectives }\end{array}$ & 3 & 4 & 4 & 4 & 4 & 1.00 & Valid \\
\hline & $\begin{array}{l}\text { The suitability of the evaluation questions } \\
\text { contained in the Lectora inspire with the }\end{array}$ & 3 & 4 & 3 & 3 & 3 & I.OO & Valid \\
\hline
\end{tabular}




\begin{tabular}{|c|c|c|c|c|c|c|c|c|}
\hline \multirow{5}{*}{ Aspect } & \multirow{2}{*}{ Indicator } & \multicolumn{5}{|c|}{ Validator } & \multirow[t]{2}{*}{ CVR } & \multirow[t]{2}{*}{$\mathrm{C}$} \\
\hline & & I & 2 & 3 & 4 & 5 & & \\
\hline & $\begin{array}{l}\text { kingdom monera material contained in the } \\
\text { material }\end{array}$ & & & & & & & \\
\hline & $\begin{array}{l}\text { The image suitability in interactive } \\
\text { multimedia based on Lectora inspire on } \\
\text { kingdom monera material }\end{array}$ & 3 & 4 & 4 & 4 & 3 & 1.00 & Valid \\
\hline & $\begin{array}{l}\text { Ease of understanding material presented in } \\
\text { interactive multimedia based on Lectora } \\
\text { inspire }\end{array}$ & 3 & 4 & 4 & 4 & 3 & $\mathrm{I} .00$ & Valid \\
\hline \multirow{3}{*}{ Language } & Ease of understanding the language used & 4 & 4 & 4 & 4 & 3 & 1.00 & Valid \\
\hline & The effectiveness of the sentences used & 3 & 4 & 3 & 4 & 3 & 1.00 & Valid \\
\hline & Use of language by enhanced spelling & 3 & 4 & 4 & 4 & 3 & 1.00 & Valid \\
\hline \multirow[t]{2}{*}{ Illustration } & $\begin{array}{l}\text { Easy navigation (the navigation button of } \\
\text { interactive multimedia based on Lectora } \\
\text { inspire) }\end{array}$ & 4 & 3 & 4 & 4 & 3 & 1.00 & Valid \\
\hline & CVI value & & & & & & 1.00 & Valid \\
\hline
\end{tabular}

Note:

CVR : Content Validity Ratio

CVI : Content Validity Index

C : Conclusion

Affective aspects are composed of three indicators namely motivation, attraction, and curiosity, and conative aspects which are composed of one indicator that is the tendency to use interactive multimedia based on Lectora inspire. The average student questionnaire responses to interactive multimedia based on Lectora inspire in small-scale trials and large-scale trials can be seen in Table 2 and Table 3.

Table 2. Results of analysis of student questionnaire responses in small scale trials

\begin{tabular}{|c|c|c|c|}
\hline \multirow{2}{*}{ Aspect } & \multirow{2}{*}{ Indicator } & \multicolumn{2}{|c|}{ Student Response } \\
\hline & & Average $\%$ & Category \\
\hline \multirow{4}{*}{ Cognitive } & $\begin{array}{l}\text { The contents understanding of interactive } \\
\text { multimedia based on Lectora inspire }\end{array}$ & $80.2 \mathrm{I}$ & Good \\
\hline & Clarity of study instructions & 79.17 & Good \\
\hline & $\begin{array}{l}\text { The display Suitability of interactive } \\
\text { multimedia based on Lectora inspire }\end{array}$ & 82.98 & Very good \\
\hline & Average Cognitive Aspects & 80.79 & Good \\
\hline \multirow{4}{*}{ Affective } & Motivation & 81.25 & Very good \\
\hline & Victory & 81.25 & Very good \\
\hline & Curiosity & 79.86 & Good \\
\hline & Average Affective Aspects & 80.79 & Good \\
\hline \multirow[t]{3}{*}{ Conative } & $\begin{array}{l}\text { A tendency to use interactive multimedia } \\
\text { based on Lectora inspire }\end{array}$ & 80.56 & Good \\
\hline & Average Conative Aspects & 80.56 & Good \\
\hline & Overall Average & $80.7 \mathrm{I}$ & Good \\
\hline
\end{tabular}


Table 3. Results of analysis of student response questionnaire on large scale trials

\begin{tabular}{|c|c|c|c|}
\hline \multirow{2}{*}{ Aspect } & \multirow{2}{*}{ Indicator } & \multicolumn{2}{|c|}{ Student Response } \\
\hline & & Average \% & Category \\
\hline \multirow{4}{*}{ Cognitive } & $\begin{array}{l}\text { The contents understanding of interactive } \\
\text { multimedia based on Lectora inspire }\end{array}$ & 84.72 & Very good \\
\hline & Clarity of study instructions & 83.33 & Very good \\
\hline & $\begin{array}{l}\text { The display suitability of interactive } \\
\text { multimedia based on Lectora inspire }\end{array}$ & 84.20 & Very good \\
\hline & Average Cognitive Aspects & 84.08 & Very good \\
\hline \multirow{4}{*}{ Affective } & Motivation & 81.95 & Very good \\
\hline & Victory & 81.77 & Very good \\
\hline & Curiosity & 85.07 & Very good \\
\hline & Average Affective Aspects & 82.93 & Very good \\
\hline \multirow[t]{3}{*}{ Conative } & $\begin{array}{l}\text { A tendency to use interactive multimedia } \\
\text { based on Lectora inspire }\end{array}$ & 84.20 & Very good \\
\hline & Average Conative Aspects & 82.20 & Very good \\
\hline & Overall Average & 83.74 & Very good \\
\hline
\end{tabular}

The results of small-scale trials and large-scale trials obtained that the overall response rate was $80.71 \%$ with a good category and $83.74 \%$ with very good criteria. This shows that students gave a positive response to interactive multimedia based on Lectora inspire that was developed.

\section{DISCUSSION}

The assessment results of the validator on the aspects of the format CVR value was I.00, the content aspect with CVR value was I.00, aspects of language with CVR value was 1.00 and the aspect illustrated with CVR value was I.00. The overall CVI value was I.00 and classified is as valid. This shows that interactive multimedia based on Lectora inspire is appropriate to be used as a medium of learning in schools.

The format aspect consists of six indicators that obtain a CVR value was $I .00$ with a valid category. The first indicator is the clarity of instructions for use. Based on the evaluation from the validator the instructions for using the navigation key are clear. This is in line with Kadaruddin (20I6) explains that one of the characteristics of multimedia learning is to be independent, meaning that multimedia should be supplemented by specific guidelines or instructions for use so that the user (user) can easily run multimedia programs without the guidance of others.

The second indicator of format aspect is the compatibility of interactive multimedia formats based on Lectora inspire. Based on the assessment of the format validator in interactive multimedia based on Lectora inspire is appropriate. According to Arsyad (2017) explains that the content of learning will be easier to understand if the information presented is arranged in a sequential or orderly format.

The third indicator of format aspect is the harmony of colors, writing, and images in interactive multimedia based on Lectora inspire. Based on the assessment of the color validator, the text and the images are harmonious. According to Arsyad (2017) explains that color is an important visual element in multimedia learning, but in color, selection must give the impression of separation, emphasis, and build an integration between elements such as displaying images and writing in the media or multimedia learning that is developed.

The fourth indicator of format aspect is the suitability of video size and video sound in interactive multimedia based on Lectora inspire as well as text that is displayed in interactive 
multimedia based on Lectora inspire. Based on the assessment from the validator the sound and video sizes are appropriate. Explaining video is a teaching material that can display images and sounds in a complete and easy to understand way.

The fifth indicator of format aspect is the suitability of the layout of the text used in interactive multimedia based on Lectora inspire. Based on the assessment results of the validator the layout of the writing is appropriate. Sitepu (2015) explained that the main consideration in determining the layout of the text is the ease of reading and being seen as a whole by students such as titles, subtitles, descriptions, tables, and diagrams displayed in multimedia in can see Figure I.

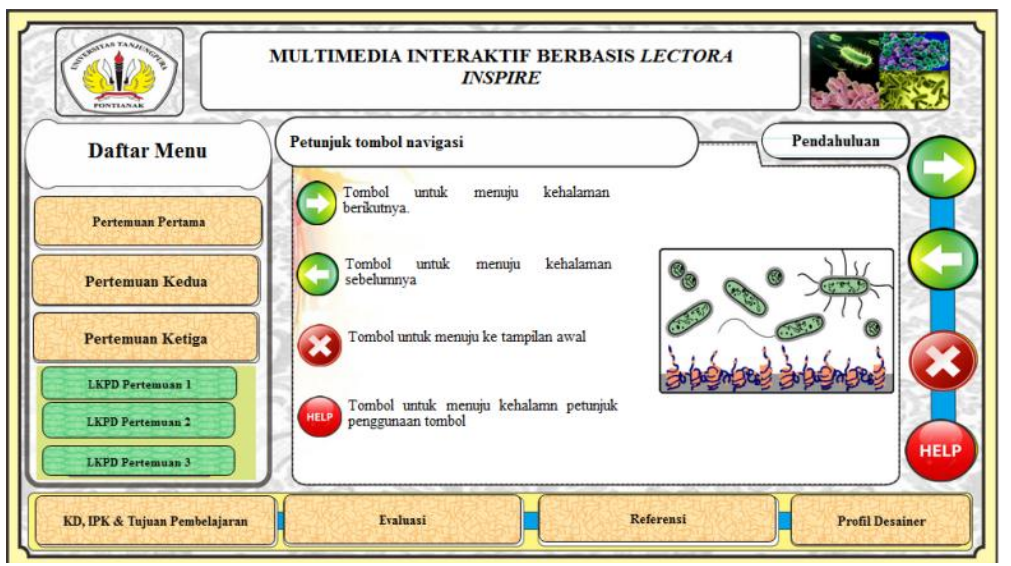

Figure I. Display format

The content aspect is composed of 6 indicators that get a CVR value is $I .00$ with a valid category. Indicator first suitability of the material content tailored to the basic competence, indicator achieving competence, and the learning objectives. Based on the assessment of the validator the content of the material is by basic competence, indicators, and learning objectives. This is in line with Kadaruddin (2016) explaining that the contents of the material contained in multimedia must be by the indicators and learning objectives that have been prepared.

The second indicator of content aspect is the clarity of the kingdom monera concept which is delivered on interactive multimedia based on Lectora inspire. Based on the assessment of the validator kingdom monera concept is clear. According to Arsyad (2017), the clarity of the concept of material in a media is very important, because the media is a learning resource whose role is in conveying messages, information, and lesson content to students to form new knowledge.

The third indicator of a content specification is the suitability of a student worksheet in interactive multimedia based on Lectora inspire with basic competencies, indicators, and learning objectives. Based on the assessment of the student worksheet validator it is by the basic competence, indicator achieving competence, and the learning objectives. According to Arsyad (2017) explains that multimedia learning must be equipped with practice and repetition so that students' knowledge and competence can survive in long-term memory. Interactive multimedia based on Lectora inspire developed has a student worksheet that can be done directly by students through an Android smartphone device. The making of a student worksheet in this multimedia refers to the format of Depdiknas (2008) consisting of basic competence, competency achievement indicators, and learning objectives.

The fourth indicator of a content specification is the suitability of the evaluation questions contained in the Lectora inspire with basic competence, competency achievement indicators, and learning objectives. Based on the validator's evaluation the evaluation questions are by BC, GPA, and learning objectives. According to Kadaruddin (2016) explained that interactive multimedia based on Lectora inspire must be equipped with evaluation questions that are used to determine 
students' understanding of the material presented and are equipped with feedback as a response to the answers given. Multimedia based interactive Lectora inspire there are 20 questions of selfevaluation multiple-choice tailored to the basic competency, competency achievement indicators, the purpose of learning materials kingdom monera, and equipped with a final score rating as a form of a feedback of choice answers selected by students. In line with this Shalikhah et al. (2017) mentions that self-evaluation that is complemented by feedback in interactive multimedia based on Lectora inspire can train independent learning and the final score (feedback) displayed can inform the achievement of knowledge directly to students. According to Riska, Didin, \& Yasinta (2018), motivation is very important in achieving learning outcomes, so the teacher can know the ability of students to follow the learning provided by the teacher if the results are satisfying students can be motivated to be able to study harder if student learning outcomes are less satisfying students are required to try and improve learning outcomes in can see Figure 2.

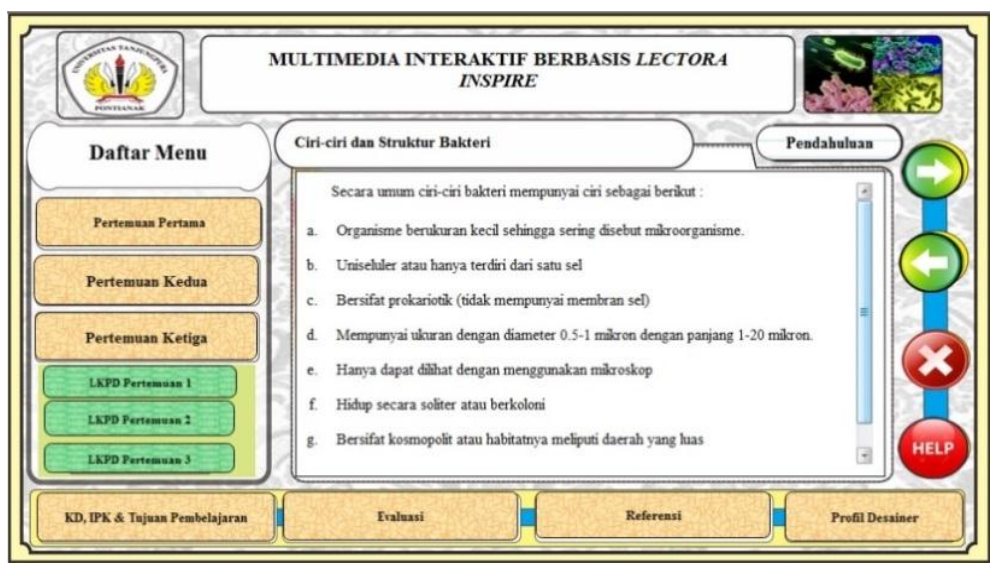

Figure 2. Display material content

The fifth indicator of a content spec is the suitability of images in interactive multimedia based on Lectora inspire on kingdom monera material. Based on the assessment in the picture validator based interactive multimedia based on Lectora inspire the kingdom monera material conforms with the image and contents. Display interesting content, the image must be by the contents of the material. The suitability of the images with the content of the material presented is interrelated, in line with this Arsyad (2017) also explained that the main purpose of using images is to visualize the concepts that they want to convey to students.

The language aspect consists of three indicators that get a CVR value was I.OO with a valid category. The first indicator is the ease of understanding the language used, the second indicator is the effectiveness of the sentence used and the third indicator is the use of language by the improved spelling. Based on the language validator's suggestion in interactive multimedia it's easy to understand. The sentence used is effective and by PUEBI. The parts that influence the readability of the Sitepu (2015) route menu, namely the order of words and sentences, the stages of word writing, paragraph format, and choice of words affect the level of readability. Sitepu (2015) states that language is used as a means to convey thoughts, ideas, and feelings from one person to another and the ability to understand and use language is influenced by the ability to think, experience, and the environment.

The illustration aspect only consists of one indicator namely ease of navigation (interactive multimedia navigation buttons based on Lectora inspire). Based on the suggestion of the navigation button validator in interactive multimedia based on Lectora inspire, it's easy to use Kadaruddin (2016) also explained that interactive multimedia is multimedia that is equipped with a controller 
so that it can be used or operated anywhere and anytime and the user can choose whatever button he wants. The display multimedia navigation button can see in Figure 3.

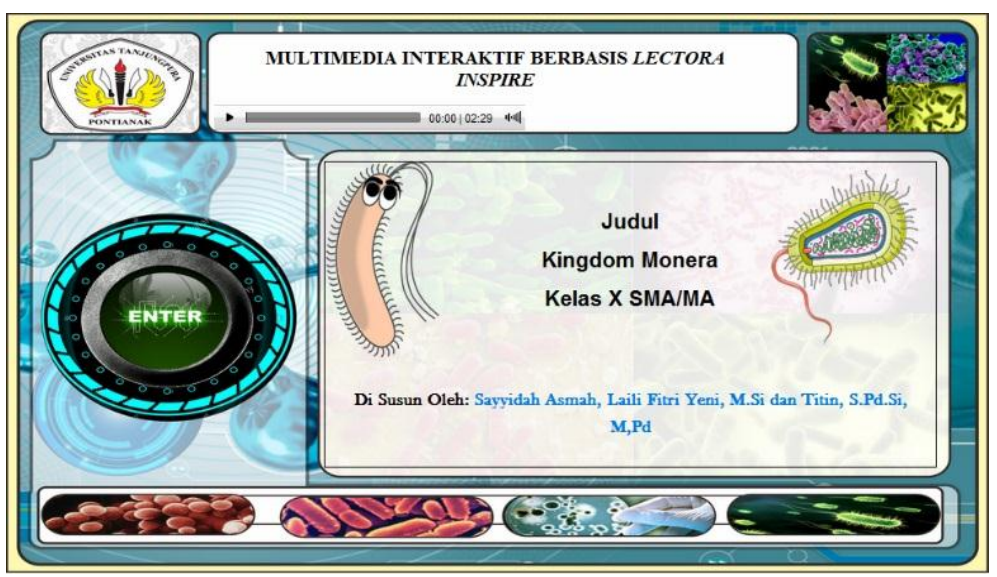

Figure 3. Display navigation button

Mahmuda \& Pustikaningsih (2019) the superiority of Lectora inspire compared to other media, that is, the software of other learning media developers. Flash content is one part of the software. Flash content includes powerful screenshots, recording, authorization tools so that you can create videos and flash content quickly. Lectora inspire also has several templates that make it easier for teachers to integrate material and evaluation in the learning process.

The results of small-scale trials can be seen in Table 2 these results indicate that students give good responses. The comments they gave showed a positive response that they understood and liked Lectora inspire media besides that they gave comments that Lectora inspire was a very interesting media, so from the suggestions they gave there was no sign that there should be an improvement. Therefore, based on the results of comments and suggestions given to the Lectora inspire media that they have used on their Android smartphones, there is no revision of the Lectora inspire media in kingdom monera material and proceed to the large-scale test stage with an overall average score was $80.7 \mathrm{I} \%$ with a good category.

The results of large-scale trials can be seen in Table 3 these results show that students gave good and positive responses with an overall score was $83.74 \%$ with a very good category. This indicates that students like and are interested in Lectora inspire media.

Based on the results of trials conducted there was an increase from small-scale trials was 80.7I\% with good category, to $83.74 \%$ with very good category conducted in large-scale trials. This shows the difference between many respondents will affect the percentage value of the student response questionnaire. This is by Amir (2015) another weakness when the sample used is small, its characteristics do not represent the population where this scale will be shown. The following is a description of the cognitive, affective, and conative aspects of small scale and large scale tests.

The cognitive aspect consists of three indicators namely understanding the contents of interactive multimedia based on Lectora inspire contents, clarity of study instructions, and the suitability of Lectora inspire appearance. In the cognitive aspect, an increase in students' responses from the small scale test cognitive aspects gained an average was $80.79 \%$ with a good category and to a large scale test gained an average was $84.08 \%$ with a very good category. The first indicator is the understanding of multimedia contents based on Lectora inspire based on this indicator, the average score for small scale test was $80.21 \%$ with a good category, while the average value for large scale test is $84.72 \%$ with a very good category. Kustandi \& Bambang (20II) explained below, learning media functions to clarify the meaning of the message conveyed, the contents of the material are arranged in meaningful sequences. 
The second indicator of the cognitive aspect that is clarity of learning instructions this indicator obtained an average value for a small scale test was $79.17 \%$ with a good category. While the average value for a large scale test is $83.33 \%$ with a very good category. According to Kadaruddin (2016) explains that one of the characteristics of multimedia learning is to be independent, meaning that multimedia should be supplemented by specific guidelines or instructions for use so that the user (user) can easily run multimedia programs without the guidance of others.

The third indicator of the cognitive aspect that is the suitability of the Lectora inspire display of this indicator obtained an average value for a small scale test was $82.98 \%$ with a very good category. While the average value of the large-scale test was 84.20 with a very good category. The use of images, colors, and appropriate videos can help students in understanding the material presented. This is in line with the opinion of Sudjana \& Rivai (2015) the images chosen to be displayed in multimedia must support the material and by the specific learning objectives, namely by choosing images that support the core content of learning and objectives.

The affective aspect consists of three indicators namely motivation, attractiveness, and curiosity. In the affective aspect, there was an increase in student responses from the small scale test the affective aspect gained an average was $80.79 \%$ with a good category to a large scale test that obtained an average was $82.93 \%$ with a very good category. The first indicator obtained an average for small scale tests was $81.25 \%$ with a very good category and an average for large scale tests that is $81.95 \%$ with a very good category. Mahmudah \& Pustikaningsih (2019) media that is interactive will help students to learn more actively and students can be motivated to follow the learning process at school.

Indicators are both affective aspects namely the attractiveness of this indicator average gain for the small-scale test was $81.25 \%$ with a very good category and earned an average of a largescale test is $81.77 \%$ with a very good category. Shalikhah (2016) using Lectora inspire subject matter is designed as attractive as possible, can display videos, as well as animated images related to the subject matter so that students pay more attention to what is conveyed by the teacher.

The third indicator of an affective aspect is curiosity, this indicator obtained an average for a small scale test that was $79.86 \%$ with a good category and a large scale test average that is $85.07 \%$ with a very good category. According to Nurfauziyah, Marjono, \& Sugiharto, (2015) the learning process begins with efforts to find patterns that have not been stated openly by the teacher so that curiosity and challenges grow in students.

The conative aspect consists of only one indicator, namely the tendency to use Lectora inspire. In the conative aspect, an increase in student responses from the small scale test the conative aspect gained an average was 80.56 and good category to a large scale test that gained an average was $84.20 \%$ and very good category. According to Arsyad (2017), the use of instructional media in the teaching and learning process can arouse new desires and interests, arouse motivation and stimulate learning activities, and bring psychological influences on students.

\section{CONCLUSION}

Interactive multimedia based on Lectora inspire in kingdom monera material is declared valid as a learning medium in schools with a Content Validity Index (CVI) value was I.00. Student responses to interactive multimedia based on Lectora inspire in kingdom monera material were good category with an overall score was $80.7 \mathrm{I} \%$ at the small scale test stage was $83.74 \%$ and very good category at the large scale test stage. Further research is needed regarding the implementation of interactive multimedia based on Lectora inspire in schools aimed at seeing learning outcomes in the kingdom monera. 


\section{REFERENCES}

Amir, T. (2015). Merancang kuesioner: konsep dan panduan untuk penelitian sikap, kepribadian dan perilaku. Jakarta: Prenadamedia Group.

Aryad, A. (2017). Media pembelajaran (cetakan ke-20 ed. revisi). Jakarta: PT. Raja Grafindo Persada.

Bustami, Y., Corebima, A.D., Suarsini, E., \& Ibrohim, I. (2017). The social attitude empowerment of biology students: implementation JiRQA learning strategy in different ethnics. International Journal of Instruction, IO(3), 15-30. Retrieved from https://doi.org/IO.I2973/iji.20I7.I032a

Cimer, A. (2012). What makes biology learning difficult and effective: students' views. Educational Research and Reviews, 73), 6I-7I. Retrieved from https://doi.org/I0.5897/ERRII.205

Daryanto. (2016). Media pembelajaran (cetakan ke-I ed. revisi). Yogyakarta: Gava Media.

Depdiknas. (2008). Panduan pengembangan bahan ajar. Jakarta: Depdiknas.

Hasyim, A. (2016). Metode penelitian dan pengembangan di sekolah. Yogyakarta: Media Akademi.

Heni, V., Duda, H.J., \& Supiandi, M.I. (2017). Penerapan metode student facilitator and explaining berbantuan media peta timbul terhadap kemampuan berpikir kritis siswa pada materi sel. JPBIO (Jurnal Pendidikan Biologi), 2(2), 20-26. Retrieved from https://doi.org/I0.31932/jpbio.v2i2.22I

Kadaruddin. (2016). Media dan multimedia pembelajaran. cetakan ke-2 ed.). Yogyakarta: Deepublish.

Kholina, N., Pribadi, T.A., \& Ridlo, S. (2013) Penerapan investigasi kelompok berbantuan multimedia materi identifikasi bakteri. Unnes Journal of Biology Education, 2(I), 26-33. Retrieved from https://journal.unnes.ac.id.index.php/ujbe/article/view/26II

Kustandi, C., \& Bambang, S. (201 I). Media pembelajaran. Bogor: Ghalia Indonesia.

Lawshe, C.H. (1975). A quantitative approach to content validity. Personnel Psychology, 28, $563-$ 575. Retrieved from https://doi.org/I0.I I I I/j.I744-6570.I975.tb0I393.x

Mahmudah, A., \& Pustikaningsih, A. (2019). Pengembangan media pembelajaran interaktif berbasis lectora inspire pada materi jurnal penyesuaian untuk siswa kelas $\mathrm{x}$ akutansi dan keuangan lembaga SMK negeri I tempel tahun ajaran 2018/209. Jurnal Pendidikan Akutansi Indonesia, I7(I), 97-III. Retrieved from https://journal.uny.ac.id/index.php/jpakun/article/view/265I5

Mas'ud, M. (2014). Membuat multimedia pembelajaran dengan lectora (cetakan ke-3 ed.). Yogyakarta: Pustaka Shonif.

Matsun, Ramadhani, D., \& Lestari, I. (2018). Pengembangan bahan ajar listrik magnet berbasis android di program studi pendidikan fisika IKIP PGRI pontianak. Jurnal Pendidikan Matematika dan IPA, Q(I), 99-I07. Retrieved from http://jurnal.untan.ac.id/index.php/PMP/article/view/23703

Muyaroah, S., \& Fajartia, M. (2017). Pengembangan media pembelajaran berbasis andorid dengan menggunakan aplikasi adobe flash CS 6 pada mata pelajaran biologi. Innovative Journal of Curriculum and Educational Technology, 6(2), 79-83. Retrieved from https://journal.unnes.ac.id/sju/index.php/ujet/article/view/I9336

Nurfauziyah, S., Marjono, \& Sugiharto, B. (2015). Penerapan guided inquiry untuk meningkatkan rasa ingin tahu siswa pada pembelajaran biologi di kelas xi ipa sma al muayyad surakarta tahun pelajaran 2014/2015. Seminar Nasional XII Pendidikan Biologi FKIP UNS. Surakarta. Retrieved from https://media.neliti.com/media/publications/I7I6I7-IDnone.pdf 
Permendikbud. (2013). Undang-undang no 70 tahun 2013 tentang kerangka dasar dan struktur kurikulum. Jakarta: Sekretariat Negara.

Purnomo, A.J. (2017). Pengembangan modul pengayaan archaebacteria dan eubacteria kelas $x$ berdasarkan penelitian bakteri penghasil enzim kitinase. Jurnal Pendidikan Biologi, 6(3), I55-I63.

Retrieved

from

http://journal.student.uny.ac.id/ojs/index.php/pbio/article/viewFile/796I/7583

Priyono, E., \& Asto, I.G.P. (20I2). Pengembangan media pembelajaran edu-game adventure pada standar kompetensi menginstalasi pe di smkn I tuban. Jurnal Pendidikan Tekhnik Elektro, I(I), I-II. Retrieved from http://urnalmahasiswa.unesa.ac.id/index.php/jurnalpendidikan-teknik-elektro/article/view/204

Rahmawati, A., \& Isroah. (2013). Penggunaan media lectora inspire x.6 untuk meningkatkan hasil belajar akuntansi siswa smk ma'arif I. Jurnal Pendidikan Akuntansi Indonesia, II(2), 9I-98, Retrieved from https://journal.uny.ac.id/index.php/jpakun/article/view/I694

Riduwan. (2015). Skala pengukuran variabel-variabel penelitian. Bandung: Alfabeta.

Riska, F., Syafruddin, D., \& Lisa, Y. (2018). Pengaruh metode guided note taking berbantuan media gambar terhadap hasil belajar siswa pada materi sistem peredaran darah pada manusia. JPBIO (Jurnal Pendidikan Biologi), 3(I), 26-32. Retrieved from https://doi.org/I0.31932/jpbio.v3iI.263

Shalikhah, N.D. (2016). Pemanfaatan aplikasi lectora inspire sebagai media pembelajaran interaktif. CAKRAWALA, II(I), IOI-II5. Retrieved from http://journal.ummgl.ac.id/index.php/cakrawala/article/view/I05

Shalikhah, N.D., Primadewi, A., \& Iman, M.S. (2017). Media pembelajaran interaktif lectora inspire sebagai inovasi belajar. WARTA LPM, 2O(I), 9-16. Retrieved from http://journals.ums.ac.id/index.php/warta/article/viewFile/2842/27I8

Sitepu. (2015). Penulisan buku teks pelajaran. Bandung: PT Remaja Rosdakarya

Sudarisman, S. (2015). Memahami hakikat dan karakteristik pembelajaran biologi dalam upaya menjawab tantangan abad 2I serta optimalisasi implementasi kurikulum 2013. Jurnal Florea, 2(I), 29-35. Retrieved from http://doi.org/I0.25273/florea.v2iI.403

Sudjana, N., \& Rivai, A. (2015). Media pembelajaran. Bandung: Sinar Baru Algemsindo

Sugiyono. (2015). Metode penelitian kuantitatif, kualitatif dan $R$ \& $D$ (Cetakan ke-20 ed.). Bandung: Alfabeta.

Suratman, D. (2019). Pengembangan bahan ajar interaktif untuk perolehan keterampilan menentukan luas daerah yang dibatasi dua fungsi. Jurnal Pendidikan Matematika dan IPA, IO(2), 2I7-223. Retrieved from http://dx.doi.org/I0.264I8/jpmipa.vI0i2.3I026

Tegeh, I.M., Jampel, I.N., \& Pudjawan, K. (20I4). Model penelitian pengembangan. Yogyakarta: Graha Ilmu.

Zakia, A.R., Refirman, D., \& Rusdi. (2019). Pengaruh pembelajaran berbasis masalah menggunakan media sosial e-learning terhadap hasil belajar siswa sekolah menengah pada sistem pencernaan. JPBIO (Jurnal Pendidikan Biologi), 4(I), 2I-28. Retrieved from http://jurnal.stkippersada.ac.id/jurnal/index.php/JBIO/article/view/395

Zuhri, M.S., \& Rizaleni, E.A. (2016). Pengembangan media lectora inspire dengan pendekatan kontekstual pada siswa sma kelas x. Phythagoras, 5(2), II3-II9. Retrieved from https://www.journal.unrika.ac.id/index.php/jurnalphythagoras/article/view/463

Zuhrieh, S.A. (2009). A pilot study to investigate the effectiveness of multimedia cd-room vis-à-vis traditional print based technology in teaching fourth grade children. International Journal on E-Learning, $\quad 8(3), \quad 403-423 . \quad$ Retrieved from https://www.learntechlib.org/primary/p/26I62/ 